\title{
Principality of Liechtenstein in Today's World
}

\author{
Maria-Pia Kothbauer / maria-pia.kothbauer@llv.li
}

Ambassador of the Principality of Liechtenstein to the Czech Republic and the Republic of Austria

\begin{abstract}
The present article presents the text of a lecture given by Her Serene Highness Maria-Pia, Ambassador of the Principality of Liechtenstein to the Czech Republic, on the occasion of the "Days of Liechtenstein History in the Czech Republic" organized by the Czech-Liechtenstein Commission of Historians on 9 November 2019 at the Moravian Museum, in the Historical Hall of the Dietrichstein Palace in Brno. The lecture dealt with the position of the Principality of Liechtenstein in the contemporary world, including the legal status of Liechtenstein, issues of its involvement and involvement in international institutions, as well as selected issues on Czech-Liechtenstein relations. As the author puts it, Liechtenstein is today a prosperous country that offers its citizens social, economic and political stability. It is a country with a fully functioning labour market, a sustainable and healthy environment, a free space in all respects and with real opportunities for political participation. The text also outlines the basic characteristics of the political, constitutional and economic systems of Liechtenstein. In further sections, she then deals with some historical factors that have led to the current position of Liechtenstein in Europe and in the world. This mainly concerns the beginnings of Liechtenstein statehood, which is traditionally associated with the purchase of the Vaduz and Vaduz counties and Schellenberg territories by the Princely House of Liechtenstein in 1699/1712, but also, the ongoing impact of events from the Second World War. In Liechtenstein at that time there was a relatively strong pro-German group called the "Volksdeutsche Bewegung", but almost 95 percent of the population was in favour of maintaining independence from the Third Reich. Following the year 1945 property of citizens of Liechtenstein was seized in Czechoslovakia, something which is still understood as an unresolved question in Liechtenstein. The motto of Liechtenstein is: For God, Prince and Fatherland! Although this might sound old fashioned, it has become the motto of the success of modern Liechtenstein, a monarchy with strong civil rights. A country in which a prince with vision has successfully sought to persuade the second sovereign, the people, when necessary. A country in which people are aware of their democratic rights, also actively pursuing them and understanding work as the core of their social DNA. A country where the government is ready to take on unpopular issues and to propose solutions that are acceptable to the people. It is not a land of miracles, but is still a successful and modern country in the middle of Europe, worth living in and connected to Europe in every way.
\end{abstract}




\section{Keywords}

Principality of Liechtenstein, House of Liechtenstein, Czechoslovakia, Czech Republic, CzechLiechtenstein Commission of historians, Czech-Liechtenstein Relations, The Days of Liechtenstein History, European Economic Area, Prince Hans-Adam II, Prince of Liechtenstein Foundation, Masaryk University

It is a great pleasure for me to be with you today in Brno and to conclude the Jubilee Year of the Principality with a very special event - the „Days of Liechtenstein History in the Czech Republic“ - here in the Czech Republic, the country to which Liechtenstein has been tied in a common history for 770 years.

Much of what has shaped Europe over the centuries reflects in this commonality and offers exciting questions not only for historians.

It is our privilege to discuss these issues with prudence and to analyze bilateral and European issues in an interested dialogue. It is precisely for this reason that I would like to express my special gratitude for this opportunity to speak about the Principality of Liechtenstein in to-day's world.

In my remarks, I will try to bring you closer to modern Liechtenstein in its self-image as a living democracy exercised directly by its citizens. I would also like to show you that, in Liech-tenstein, nature and a well-preserved environment maybe in perfect harmony with the re-quirements of an attractive and innovative industrial and business location. Finally, I would like to discuss the significance of the relations between our two States in the present and in the future.

First of all, however, I would like to thank our host, the Director General of the Moravian Museum, Mr. Jiří Mitáček, as well as Dr. Dagmar Grossmannová with her team and Prof. Tomáš Knoz for inviting me to speak to you today.

In particular, I would like to thank all those who made such an effort to conceive a wonderful program and an impressive supporting program for the „Days of Liechtenstein History in the Czech Republic“. We Liechtenstein citizens appreciate this very much.

Our gratitude goes to

- University and Faculty of Philosophy (Prorector Hanuš), Institute of History, Institute for German Studies, Institute for Bohemian Studies and to the partner institutions:

- $\quad$ the Moravian State Archives (Director Dr. Macek and Dr. Černušák with his team)

- $\quad$ the Moravian National Library (Director Prof. Kubíček and Dr. Heilandová with their team)

- $\quad$ the Secondary School of Art and Design (Mgr. Vybíral, head of the Photography Studio)

- $\quad$ and last but not least, to the Ministry of Foreign Affairs of the Czech Republic, especially to my dear colleague and friend Ambassador Tomáš Kafka. 
Of course, our gratitude also goes to all members of the Liechtenstein-Czech Commission of Historians for the preparation of the Days of Liechtenstein History in the Czech Republic.

In the nearly 10 years of its existence, the Commission of Historians has made a tremendous effort and developed the common history in an academically exemplary manner. The results have been published in eight very successful volumes and have also been made available to all interested parties on a homepage.

The history of the Liechtenstein family and thus of the country of Liechtenstein is deeply rooted in the core countries of Central Europe, the Czech Republic and Austria. Moravia holds a very special position in this respect.

The cultural landscape and the castles of Lednice and Valtice are of course the most im-portant witnesses of these ties. The great Ottakar II transferred the first property of the family in Moravia to Henry of Liechtenstein in the village of Nikolsburg/Mikulov in 1249.

The work of the House of Liechtenstein is still clearly visible today in Brünn/Brno, Sternberg/Šternberk, Lundenburg/Břeclav, Adamsthal/Adamov, Gross Ullersdorf/ Velké Losiny, Wranau/Vranov, but also in Prague and Schwarzkostelec/Kostelec nad Černými lesy. It is said that there are about 600 locations, and it is not only about the famous castles, but also about places of crafts, industry and culture. They are an integral part of the cultural heritage we share with you, which, fortunately, is increasingly uniting us again.

It is thus no coincidence that this interest in our commonalities is held high by the universities of Moravia, in particular by Masaryk University. We are grateful for that.

In this context, I would like to remind you of Prof. František Weyr, former rector and co-founder of the Faculty of Law of the University of Liechtenstein, who in the difficult 1930s and 1940s unswervingly and courageously made his expertise available to the House of Liechtenstein, then represented by my father, Prince Karl-Alfred von und zu Liechtenstein.

The award of the Grand Gold Medal of the Masaryk University to Prince Hans Adam II von und zu Liechtenstein in 2011 by the then Rector and current Chairman of the ODS, Petr Fiala, was also a sign of recognition of the efforts made to develop CzechLiechtenstein relations.

I would also like to mention an event that took place last week.

On the 100th anniversary of the Mendel University, the Rector of the University, Prof. Danuše Nerudová, awarded the Golden Medal to our acting Head of State, Hereditary Prince Alois von und zu Liechtenstein, for the services rendered by the House of Liechtenstein to the founding of the University in a very dignified ceremony, a beautiful and generous gesture of appreciation of the family.

It is of particular importance to us, however, that this outstanding university of agriculture and forestry, economics and regional development is also today in close cooperation with the agricultural and forestry experts of the Prince of Liechtenstein Foundation, and that a confer-ence is currently taking place on the pressing issues of sustainable management in times of climate change and the associated challenges. 
In times of very concrete threats, such as the rise in temperature or the bark beetle in Central Europe, the cooperation between practitioners and universities is indispensable in order to preserve a resilient agricultural and forestry substance and, if necessary, to develop new forms and cultures.

Relations between our countries had been interrupted for 70 years until diplomatic relations were resumed in 2009. It was the Velvet Revolution that we commemorate these days with joy and esteem, which enabled a new engagement with history, including that of the family and the country of Liechtenstein.

The fact that this happened so openly at Masaryk University is thanks to Prof. PhDr. Tomáš Knoz, who, as long-time co-chair of the joint commission of historians, played such an outstanding role in researching our history while ensuring that this knowledge is accessible to a broader public, and discussed in the academic discourse.

It is especially important for young people to deal with all the questions of their history themselves based on the historical facts and documents they have obtained through their research, and to judge for themselves how they see the contribution of the large old families to their country over time.

The Days of Liechtenstein History impressively demonstrated the diversity of aspects and activities, as well as the density and depth of relations between our two countries. They show the opportunities, but also the challenges of this long relationship that has lasted for more than 700 years.

This brings me to the essence of my speech, the Liechtenstein of today.

Liechtenstein is a country with almost forty thousand inhabitants. It is the only member state of the Holy Roman Empire that has been able to develop in its unchanged territory since its foundation 300 years ago.

For centuries, this Alpine region was initially a barren and poor agricultural country, equally threatened by high mountains and the formerly unregulated Rhine. Since the 1950s, however, it has slowly but surely developed into a small but extremely successful industrial nation. Sim-ilar to the Czech Republic, it has a high proportion of forests and agricultural land, which en-sure a sustainable environment worth living in.

Today, Liechtenstein offers its citizens unprecedented prosperity, along with social, economic, and political security and stability. It is a country that provides jobs, far more than its popula-tion could provide, sustainable and healthy living conditions, freedom in every respect, and genuine political participation.

Was this just good luck, fate or the hard-earned success of the citizens and leadership of the country?

This path, this development and this ascent had not exactly been laid in the cradle of the country and its people when, after long efforts by the Princely House, Charles VI granted his former teacher and comrade-in-arms in the War of the Spanish Succession, Anton Florian of

Liechtenstein, the elevation of the country newly merged from the County of Vaduz and the Dominion of Schellenberg to the status of the self-governing Principality of Liechtenstein.

Yes, there was also luck, coincidence and the like coming into play! 
For example, the fact that the Principality still has two ideal and federal neighbors, Austria and Switzerland, with whom it is closely connected both amicably and professionally. Moreover, although the national borders of the Principality have not changed since its foundation, the country's situation has not always been as good and uncomplicated as it is today.

Of course, there were times when the existence of the small state was at the brink.

Since the central issue of Liechtenstein foreign policy - i.e. the preservation of sovereignty and the independence of the country - became the topic at each of these historical cliffs, I would like to show in more detail and with concrete historical events what it is all about to this day and how cleverly, skillfully, and resolutely the Prince and People of Liechtenstein stood up for the right to self-determination and the independence of their country in the three centuries of its existence.

I also emphasize this aspect because the recognition of this sovereignty also has to do with our bilateral issues today.

My first example dates back to the Napoleonic Wars. There has been much discussion among historians as to why in 1806 Napoleon granted sovereignty to the close advisor and general of his adversary Emperor Franz, Prince Johann I, by membership of the Rhein Confederation after the dissolution of the Holy Roman Empire, as most of the small states of the Empire lost their sovereignty.

One spoke of a respectful gesture of the Napoleon towards the prince, who did not even renounce to serve his emperor as a counselor as well as a soldier. This sovereignty was then confirmed in the Congress of Vienna, in which Liechtenstein and Luxembourg were admitted as states to the German Confederation, the only of the previously incalculable number of small states.

Liechtenstein's integrity had previously been violated from all sides, once by the French troops besieging the city of Feldkirch, another time by defeated, retreating Russian troops, and as always it was the population who had to bear the burdens of the war by quartering and handing over its own bitterly needed food.

Often hardly known is the next evidence of Liechtenstein's active sovereignty policy, the neutrality that it declared in the First World War. This was a fact which, according to the British Foreign Office, would have entitled the country to take part in the peace negotiations in Paris. After all, Liechtenstein was then officially codified as part of Austria's national borders in the Treaty of St. Germain.

Not as long ago, albeit already 80 years ago, there was the threat to Liechtenstein by Nation-al Socialism. Especially in the long-suffering Czech Republic, it is important for me to recall this chapter of Liechtenstein history.

It was the evening of 24 March 1939 - Czechoslovakia had already become a victim of the Third Reich on 15 March and Austria in the previous year - when the National Socialist Volksdeutsche Bewegung in Liechtenstein tried to force the annexation of the Principality to Germany. It was planned to provoke clashes by a march on Vaduz and subsequently to let German forces from Feldkirch enter Liechtenstein after a call for help.

The National Socialists were already marching in the direction of Vaduz, but were prevented from implementing their plans in all municipalities by defensive opponents 
of the Nazis, led by the intrepid government councilor at the time, Canon Anton Frommelt.

The coup attempt led to great indignation and to the patriotic "closing of the ranks" in the country. In the days following the event, the Liechtenstein Patriot Association launched a petition to affirm Liechtenstein's independence, combined with a commitment to the Princely House and to the economic and political orientation to Switzerland. A remarkable $95.4 \%$ of all voters signed.

And a final example of the anxious days of May 1945 was when a group of about 600 Russian soldiers, who had fought alongside Hitler against the Soviet Union, penetrated the territory past the Swiss customs guard in order to escape arrest and ultimately the deathly extradition to the Soviets by the Western Allies. Liechtenstein opted for a humanitarian stance, even though this was not popular either in the West or in the East.

So there were very different threat images with which Liechtenstein was confronted over the centuries, and they were encountered in very different ways, but at least with skill, courage and understanding of what is good and acceptable for one's own country - also from a moral point of view - and probably also with a good sense of what can be expected of others.

In any case, that was more than pragmatism. That was rectitude and firmness of character.

An important point, previously seen as weakness, was the small size of the state. It has indeed become a virtue.

Since a small state cannot expect to have much economic, political or even military power, it was clear that we see integration, whether into the neighborhood, the region, the European state structure or even into the community of all states in the world, the United Nations, not as a loss of sovereignty, but as a strengthening of our position, as a gain in sovereignty. This is true for all levels, in politics, in the economy, in culture or in education.

What constitutes the State of Liechtenstein, the Principality of Liechtenstein today?

Liechtenstein is one of the most highly industrialized countries in the world, with an innova-tive service sector in which free enterprise and outstanding employees provide a remarkable economic performance that forms the basis of our prosperity.

The state certainly has an important role to play in creating a business-friendly and sustaina-ble infrastructure and a social regulatory framework that enables innovation and at the same time offers citizens rights and protection where necessary.

The state quota is deliberately low. With about 850 civil servants, the ratio of $21 \%$ is less than half that of Austria (48\%) or Germany (44\%) and one third less in relation to Switzerland (33\%). At 41\%, the Czech Republic is well below the European average of around $46 \%$.

It is the government's declared goal not to primarily administer the state, but to actively shape it with foresight, especially in times of considerable change.

For Alemannic, these are not empty slogans, therefore an example: As early as 2015, the Liechtenstein Financial Market Authority set up a Regulatory Laboratory to accompany new developments in the financial services sector ab ovo. In essence, it is about technology neu-trality in the financial sector. We make new things possible - especially 
in times of digitalization, and at the same time, we ensure that not anything worthy of protection falls out of reg-ulation.

In a larger context, that means: The state should offer stability, but it must also allow agility and innovation, and at best make them possible and promote them.

The Principality of Liechtenstein is firmly committed to the fundamental European values of the rule of law, democracy, and the preservation of human rights. We oppose isolation and nationalism.

Of course, this comes as no surprise, knowing that the Principality of Liechtenstein generates $55 \%$ of its GDP from exports. Nationalism, protectionism and isolationism would be dangerous for a country that offers more jobs than it has inhabitants.

The population is aware that a small state needs openness of systems and markets beyond the skills and work of its citizens to continue this successful course. However, this attitude of openness does not solely rest on economic considerations; it is fundamental and widely ac-cepted.

Our population actively participates in political events. Liechtenstein is a country of direct democracy, in which the people very often vote directly on political issues.

The Constitution names two sovereigns, the Prince and the people.

It is a sign of the political maturity and strength of the country that direct democracy and stability are in perfect harmony, certainly also because there is a strong consensus on the basic direction and function of the state.

Let me give you another concrete example of this.

In order to ensure the sustainability of pension and health care systems, the Liechtenstein Government proposed reforms that called for substantial cuts and additional burdens for citizens. Nevertheless, the people voted for both projects, and Liechtenstein remains debt-free.

Liechtenstein citizens are diligent, flexible, and pragmatic, and not only seize the moment at major historical junctions.

It was Prince Hans-Adam II who was the first to recognize the necessity of sovereignty within the modern community of states and its integration into European structures. He led Liech-tenstein into membership of the United Nations and the European Economic Area.

What was still widely rejected when Liechtenstein applied for membership of the League of Nations in 1920 was successful when it joined the UN in 1990. Since then, Liechtenstein has actively shaped its membership in the UN with a number of important initiatives of its own, be it in the fight against human trafficking, the promotion of the rule of law, or in the field of international criminal justice.

Of equal importance were the vote in 1992 and the accession to the European Economic Area in 1995, which was rejected by the Swiss population. Liechtenstein took its own autonomous path without calling into question its traditionally close relations with Switzerland, with which the country is linked in a customs union.

Liechtenstein's accession to the EEA was a correct and above all important decision for the country, which opened and secured the markets of both the EU and the EFTA countries and anchored Liechtenstein politically in the European structures. The people of Liechtenstein voted for open markets and were rewarded not only with full employment, but 
with one of the highest industrialization rates in the world. EU citizens take $44 \%$ of jobs.

This also means, however, that this success story not only secures prosperity in the country itself, but also makes a positive contribution far beyond, to the Austrian Vorarlberg and the Swiss cantons of St. Gallen and Graubünden.

Liechtenstein is successful today with many of its companies in the world market, some even as world market leaders, and others in niches as technology champions. They owe their innovative strength to agile entrepreneurship, a well-trained and creative workforce with a high level of commitment, political stability in the country, and considerable investments in educa-tion, research, and development. This is also a fact that speaks for itself: Liechtenstein's R\&D ratio is a proud 9\% of GDP.

This is the point at which I would like to discuss the current state of relations between our countries.

And I will stick to the economic aspect. Since the Czech Republic joined the EU in 2004, both countries have been closely linked through the EEA and belong to the same economic area. In a sense, both countries are as closely connected with this step as they were at the time of the Danube Monarchy.

The agreement on the European Economic Area and the double taxation agreement concluded in 2014 form a solid basis for the close and growing economic exchange between our countries.

It may not be so well known, but a component of your highly successful Škoda vehicles comes from Liechtenstein, where Thyssenkrupp Presta has been producing steering columns for the Czech automotive industry for years. Or what connects Windsor Castle, the Vatican, the Wembley Stadium and the National Theatre in Prague? They are all heated by heating systems from the Hoval Group in Liechtenstein. I don't want to go into Liechtenstein, the world market leader in dental technology, any further. Or the Hilti company, which is very successful in the Czech Republic and covers a number of other Eastern European markets from the Czech Republic to the Russian Federation. Liechtenstein companies provide over 300 jobs in the Czech Republic.

The Czech Republic is probably 500 times bigger than Liechtenstein, but even small countries are equal partners, not only in the modern basic understanding of international law, but also because even a small market participant can offer top quality, and that is exactly what the industrial and service sectors of Liechtenstein stand for.

In relation to our size, we are among the top exporters and generally generate a large sur-plus. On the other hand, you will be pleased to hear that we have a slight deficit in trade with the Czech Republic in your favor. There is still considerable potential for both sides.

I already mentioned cooperation in the field of forestry. For this purpose, there are various initiatives of the Prince of Liechtenstein Foundation that also extend to cooperation in the field of tourism. Austria with the Lower Austrian Weinviertel is also involved. A concrete pro-ject sponsored by Interegg connects South Moravia and Lower Austria and runs under the motto „Borderless Liechtenstein“ - a beautiful title. The program is aimed at cyclists, people interested in culture and wine lovers.

The cooperation in the field of education is very successful. The annual pupil exchange between the Liechtenstein Gymnasium Vaduz and the Matyáš-Lerch-Gymnasium 
in Brno is very pleasing. The program, which has existed since 2014, is co-financed by the EEA financing mechanism.

Cooperation at the university level has also developed very well. Almost 90 Czech students have studied at the University of Liechtenstein in recent years. This is remarkable considering that only economics and architecture are offered at the University of Liechtenstein and are taught largely in German. The University of Liechtenstein connects with three Czech universities via a cooperation.

The innovative foreign language program „Liechtenstein Languages“, developed in Liechtenstein, has gained a foothold in Prague this year and is used in English lessons in six schools. The Liechtenstein Minister of Education, Dominique Hasler, only visited such a school in Prague last week.

In the field of culture, notable exhibitions were held in Prague and Troppau. Liechtenstein artists are guests at various Czech festivals.

Next week in Prague, the play „Identity Europe“, eight monologues by eight authors from eight countries, will be performed as part of the renowned theatre festival of the German language in Prague, a collaboration of three European theatres, including the Theater am Kirchplatz (TAK) in Schaan.

Dear Ladies and Gentlemen

Liechtenstein does not share this density of cooperation with any other state except its immediate neighbors Austria and Switzerland, both in historical relations and in current initiatives. Deep ties bind us together. They reach into the past, for example to Vranov, where almost all the princes of our house are buried. They also include the future heir to the throne, who bears the name of Saint Wenceslas.

At the same time, we also have a historical burden to cope with.

With no other country, we are facing such serious bilateral challenges as with the Czech Republic. They touch on fundamental questions of interstate relations, such as the recognition of sovereignty and the sovereign equality of states.

The Czech Republic's suit against the Foundation of our Head of State in 2014, only a few years after the resumption of diplomatic relations, shows that open questions do not simply disappear, but, if they remain unresolved, are always likely to burden the good relationship itself.

We should overcome this together and I hope that I will not become too lyrical when I quote Hölderlin:

"The dissonances of the world are like lovers" disputes. Reconciliation comes in the middle of an argument, and all that is divided is again recouped."

In this sense, it is the goal of the Liechtenstein Government to actively shape the common future with the Czech Republic and to cooperate even more closely. This also means discuss-ing the outstanding issues in terms of reconciling interests among partners. The Princely House has also made far-reaching proposals for engagement in and cooperation with the Czech Republic.

I would like to sum up now and round off the picture of the broad historical ties we share from the beginnings under King Ottokar here in Moravia to Liechtenstein's role in today's world. 
Our history is the story of the rise of a dynasty, of the establishment of the independent state of Liechtenstein, of its remarkable success as a small state, and of the strong will of the people and their prince to foster and maintain the independence of their state.

It is a history of struggle for international anchoring and recognition and for the active shap-ing of sovereignty. This path was initially hard and full of privations. By a population motivat-ed by work and achievement, it has brought prosperity, peace and freedom to the citizens of Liechtenstein that would have been unimaginable for earlier generations of this country.

It is also a model that shows the way to accept change in a society radically challenged by technology, to seize it as an opportunity and to use it, while at the same time remaining fair to the essence of man, who expects self-determination, participation in decisions, work, edu-cation and social security for the success of his life, that of his family and his environment.

The motto of the country is: For God, Prince and Fatherland!

This sounds like the 19th century.

It has developed into the motto of the success story of modern Liechtenstein, a monarchy with strong civil rights;

A prince with visions who, when it came down to it, successfully fought for the conviction of the second sovereign, the people;

A people that is aware of its democratic rights while actively exercising them. A people that considers achievement the core of its social DNA;

A government that is prepared to tackle even the unpopular issues and to develop solutions that are accepted by the people.

No country of miracles, but a successful, modern and livable country in the heart of Europe that links with Europe in every respect.

An example for others?

Not in all cases, but certainly in some!

\section{Resumé}

\section{Lichtenštejnské knížectví v dnešním světě}

Předkládaná stat̉ přináší text slavnostní přednášky pro veřejnost, přednesené Její Jasností Marií-Piou Kothbauer, velvyslankyní Knížectví Lichtenštejnsko v České republice, při přiležitosti „Dnů lichtenštejnské historie v České republice“ pořádaných Česko-lichtenštejnskou komisí historiků dne 9. listopadu 2019 na půdě Moravského zemského muzea, v Historickém sále Dietrichsteinského paláce v Brně. Přednáška se zabývala postavením Knížectví Lichtenštejnsko v současném světě, mj. právním postavením Lichtenštejnska, otázkami jeho suverenity a zapojením do mezinárodních institucí, a také vybranými otázkami Česko-lichtenštejnských vztahů. Lichtenštejnsko je dnes podle autorčina vyjádření prosperující zemí, která svým občanům nabízí sociální, hospodářskou a politickou stabilitu. Je to země s velmi dobře fungujícím pracovním trhem, udržitelným a zdravým životním prostředím, svobodným prostorem ve všech ohledech a skutečnou možností politické 
participace. V textu se dále objevují základní charakteristiky politického, ústavního a ekonomického systému Lichtenštejnska. V dalších částech se potom věnuje některým historickým souvislostem, které vedly k současnému postavení Lichtenštejnska v Evropě a ve světě. Především se to týká počátků lichtenštejnské státnosti, jež je tradičně spojována s koupí panství Vaduz a Schellenberg Knížecím domem Liechtensteinů v letech 1699 a 1712. Důležité místo v dějinách Lichtenštejnska zaujímají také události z období druhé světové války. V Lichtenštejnsku v této době působila proněmecká skupina, která se nazývala „Volksdeutsche Bewegung“, takřka 95 procent obyvatelstva se však vyslovilo pro zachování samostatnosti. Mezi historické obrazy doby druhé světové války pro dnešní Lichtenštejnsko zcela přirozeně náleží také události po konci války, kdy došlo $\mathrm{k}$ odsunu lichtenštejnských občanů z tehdejšího Československa, což je v Lichtenštejnsku dodnes chápáno jako otevřená otázka. Moto Lichtenštejnska zní: Za Boha, knížete a vlast! Přestože podle vyjádření Marie-Pii Kothbauer zní poněkud zastarale, stalo se heslem úspěchu moderního Lichtenštejnska, monarchie se silnými občanskými právy. Země, v níž kníže s vizí úspěšně usiloval o to, aby v př́i padě potřeby přesvědčil druhého suveréna, lid. Země, v níž si je lid vědom svých demokratických práv, tyto také aktivně vykonává a chápe práci jako jádro své sociální DNA. Země, v níž je vláda připravena vypořádat se také s nepopulárními tématy a navrhnout řešení, která budou pro lidi přijatelná. Není to země zázraků, ale přesto se jedná o úspěšnou a moderní zemi uprostřed Evropy, ve které stojí za to žít a která je ve všech směrech propojená s Evropou. 
